\title{
Synthesis, Spectral and Biochemical Studies of New Complexes of Mixed Ligand Schiff Base and Anthranilic Acid
}

\author{
SABA H. MAHDI and LEKAA K. ABDUL KAREM* \\ Department of Chemistry, College of Education for Pure Sciences, Ibn -Al-Haitham, \\ University of Baghdad, Adhamiyah, Baghdad,10001, Iraq. \\ ${ }^{*}$ Corresponding E-mail: dr.likaakhalid@gmail.com \\ http://dx.doi.org/10.13005/ojc/340349
}

(Received: March 17, 2018; Accepted: May 27, 2018)

\begin{abstract}
In this research, new mixed ligand Schiff base complexes of $\mathrm{Mn}(\mathrm{II}), \mathrm{Co}(\mathrm{II}), \mathrm{Ni}(\mathrm{II}), \mathrm{Cu}(\mathrm{II})$, $\mathrm{Cd}(\mathrm{II})$, and $\mathrm{Hg}(\mathrm{II})$ are formulated from the Schiff base ( $\mathrm{L}$ ) resulting from o-phathalaldehyde (o-PA) with $p$-nitroaniline ( $\mathrm{p}-\mathrm{NA}$ ) as a primary ligand and anthranilic acid as a subordinate ligand. Diagnosis of prepared ligand and its complexes is done by spectral methods as mass spectrometer; ${ }^{1} \mathrm{H}$-NMR for ligand Schiff base FTIR, UV-Vis, molar conductance, elemental microanalyses, atomic absoption and magnetic susceptibility. The analytical studies for the all new complexes have shown octahedral geometries. The study of organicperformance of ligand Schiff base and its complexes show various activity agansit four type of bactria two gram (+) and two gram (-) .
\end{abstract}

Keyworde: ligand schiff base, microanalyses, biological activity.

\section{INTRODUCTION}

Schiff base stands for an imperative type of ligand in chemical coordinating to find comprehensive enforcement in diverse domains as biological, inorganic, analytical, and artificial chemistry branches ${ }^{1,2}$. Schiff bases are derived from aromatic-carbonyl compounds, and they have been more studied in linkage with metal ion ${ }^{3}$. Tetra dentate schiff bases $\left(L_{1}-L_{3}\right)$, which drevied from the reaction of o-phthalaldehyde with 2-amino benzyl alcohol, 2-amino-2-methyl-1-propanol, and 2-aminobenzohydrazine, have been reacted with
$\left[\mathrm{RuCl}_{2}(\mathrm{DMSO})_{4}\right]$. The prepared ligand and their complexes are characterized by spctroscopic methods ${ }^{4}$. Macrocyclic Schiff base metal complexes, derived from o-pathalaldehyde, have recently been reported by Shaker and et al., through Template method $^{5}$. New three complexes are prepared from o-phthalaldrhde with cobalt(II), nickel(II) acetate andperchlorate salts $\mathrm{VO}(\mathrm{II})$. The complexes are diagnosed by physiochemical instrument molar conductivity, FTIR, and elemental analysis ${ }^{6}$. Studies towards synthesis of new coordination compounds and their catalytic activities have been continued. Ponnusamy and co-works synthesized $\left(\mathrm{N}_{4}\right.$ and

This is an Open Access article licensed under a Creative Commons Attribution-Non Commercial-Share Alike 4.0 International License (https://creativecommons.org/licenses/by-nc-sa/4.0/), which permits unrestricted Non Commercial use, distribution and reproduction in any medium, provided the original work is properly cited. 
$\mathrm{N}_{2} \mathrm{O}_{2}$ ) tetradentate ligands of the o-pathalaldehyde (o-PA) by the non-mould method, and Co, pd and $\mathrm{Ru}$ complexes ${ }^{7}$. Schiff base ligand is derived from the concentration of o-phthalaldehyde with the glycyl glycine amino acid. The data have been described using analytical, spectral, thermal, and magnetic data. Further more, these metal complexes have also been applied as potential antibacterial agents ${ }^{8}$. Synthesis and catalytic applications of the Schiff base ligand with metal (II) transition are derived from o-pthalaldehyde ${ }^{9}$. In this work, we have prepared and characterized new complexes with mixed ligand Schiff base and anthranilicacid with some metal ions.

\section{MATERIALS AND DEVICES}

All chemicals, used in laboratory work, are of highest purity that does not need any further purity, and they have been purchased from distigushed sources. Melting points are carried out via Stuart Melting Point Kit. Elemental micro analysis of the ligand was conducted by Euro (EA 3000) instrument. ${ }^{1} \mathrm{H}$ NMR spectra are obtained using Brucker DRX system (400 MHz). UV-Vis spectra are performed on a Shimadzu UV- 160A Ultra Violet-Visible Spectrophotometer in $\mathrm{KBr}$ discs on (4000-400 $\mathrm{cm}^{-1}$ range. The IR-spectra are verified by FTIR - 8400 S Spectrophotometer. Metal contents (A.A.S) of the complexes are carried out, using atomic absorption method by means of $A A$ 620G Shimadzu spectrophotometer. The Chloride substances of compounds are specified by testing all complexes and decomposed with Nitric acid, and diluted with water. Results of the magnetic measures are found out by using Bruker BM6 instrument at room temperature and the Faraday's method.

Synthesis of (N,N'E,N,N'E)-N,N'-(1,2-phenylenebis (methan-1-yl-1-ylidene))bis(4-nitroaniline) (L)

A solution of 4-nitroaniline $(0.276 \mathrm{~g}, 2 \mathrm{~mol})$

in $10 \mathrm{ml}$ ethanol has been inserted to a mixture solution of o-phthalaldehyde $(0.134 \mathrm{~g}, 1 \mathrm{~mol})$ in $5 \mathrm{ml}$ ethanol and three drops of glacial acetic acid, and the product combination has been refluxed for $4 \mathrm{~h}^{10}$. The resulted brown solid is composed by filtration, recrystallisation from aceton absolute, and dried under m.p $\left(189{ }^{\circ} \mathrm{C}\right)$, yield $87 \%$ Schem -1 .

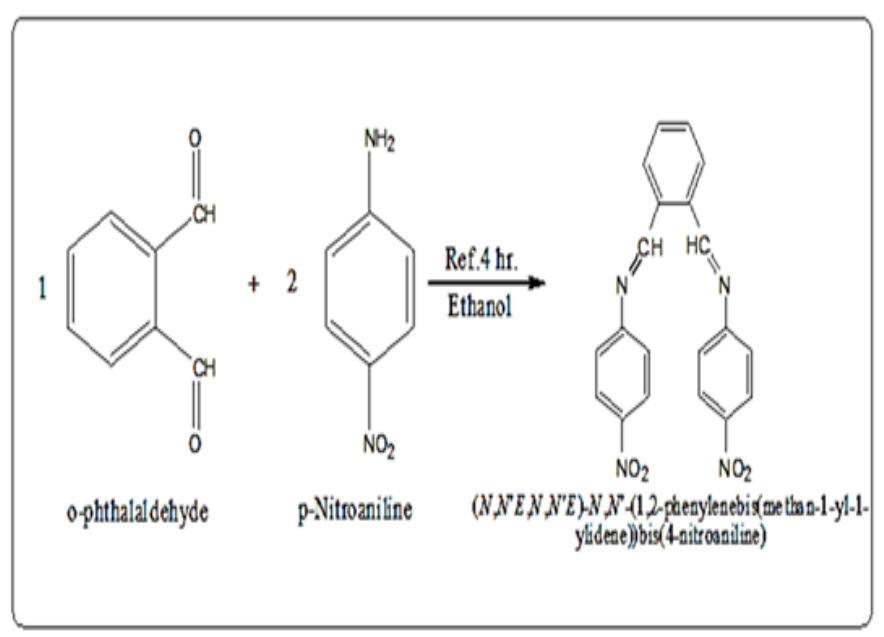

Scheme 1. The synthesis route of the ligand $L$

\section{Synthesis of the Mixed Ligand Complexes}

A solution of Schiff base ligand $(0.374 \mathrm{~g}$ $1 \mathrm{mmol}$ ) in $5 \mathrm{ml}$ absolute ethanol, (anthranilic acid $0.274 \mathrm{~g}$ and $\mathrm{NaOH} 0.08 \mathrm{~g}) 2 \mathrm{mmol}$ are added to stirred (1 mmol of metal chlorid) in $10 \mathrm{ml}$ ethanol; $0.126 \mathrm{~g} \mathrm{Mn}(\mathrm{II})$ chloride, $0.237 \mathrm{~g} \mathrm{Co}(\mathrm{II})$ chloride. $6 \mathrm{H}_{2} \mathrm{O}$, $0.237 \mathrm{~g} \mathrm{Ni}(\mathrm{II})$ chloride. $6 \mathrm{H}_{2} \mathrm{O}, 0.17 \mathrm{Cu}$ (II) chloride. $2 \mathrm{H}_{2} \mathrm{O}$, $0.201 \mathrm{~g} \mathrm{Cd}(\mathrm{II})$ chloride. $\mathrm{H}_{2} \mathrm{O}$, and $0.272 \mathrm{~g} \mathrm{Hg}(\mathrm{II})$ chloride. The product mixture is stirred for sixty minutes and, then, the result is filtered and dried through anhydrous $\mathrm{CaCl}_{2}$. The physical properties of Schiff ligand and new compounds.

\section{Biological Activity}

The Schiff base and their metal compounds were investigated with four bacteria psuedomonas 
aruginosa, Escharia coli, Staphylococcus aureus and Streptococcus pyogenes by disc diffusion technique. The chemical solutions, used in the biological study, are prepared by using dimethyl sulfoxide (DMSO) as solvent, and they are provided as a single concentration of $1 \times 10^{-3} \mathrm{M}$. The dishes were incubated at room temperature for 24 hours. The inhibition zones (IZ) in $\mathrm{mm}$ is formed after $24 \mathrm{~h}$ as a criterion for the intensity of the synthetic chemical compound effect on the outgrowth of cultivated specific bacteria strains.

\section{RESULT AND DISCUSSION}

Generally, all the complexes are soluble in DMSO and DMF but insoluble in water. The CHN analysis and the sensible features of the compounds are listed in Table-1. The complexes can be symbolized as $\left[\mathrm{M}(\mathrm{L})(\mathrm{Anth})_{2}\right]$ where $\mathrm{M}=$ metal(II) ions, ( $L=S$ chiff base ligand), and (Anth= anthranilic acid ).

Table 1 : The details of Schiff base ligand and new compounds

\begin{tabular}{|c|c|c|c|c|c|c|c|c|c|}
\hline \multirow[t]{2}{*}{ Complexes } & \multirow[t]{2}{*}{ Code } & \multirow[t]{2}{*}{ M.wt } & \multirow[t]{2}{*}{ m.p. ${ }^{\circ} \mathrm{C}$} & \multirow[t]{2}{*}{ Color } & \multicolumn{5}{|c|}{ Theoretical ( Calc.) } \\
\hline & & & & & C & $\mathrm{H}$ & $N$ & O & $\mathrm{M}$ \\
\hline $\begin{array}{l}\mathrm{C}_{20} \mathrm{H}_{14} \mathrm{~N}_{4} \mathrm{O} \\
\mathrm{Mn} \text { (L)(Anth) }\end{array}$ & L & 347.35 & $187-189$ & 39 Brown & 64.17 & 3.77 & 14.97 & 17.10 & ---- \\
\hline $\begin{array}{l}\mathrm{C}_{34} \mathrm{H}_{26} \mathrm{MnNN}_{6} \mathrm{O}_{8} \\
\mathrm{Co}(\mathrm{L})(\text { Anth })_{2}\end{array}$ & $\mathrm{C} 1$ & 701.54 & $250 P$ & Pail - brown & 58.21 & 3.74 & 11.98 & 18.24 & $7.83(7.03)$ \\
\hline $\begin{array}{l}\mathrm{C}_{34} \mathrm{H}_{26} \mathrm{CoN}_{6} \mathrm{O}_{8} \\
\mathrm{Ni}(\mathrm{L}) \text { (Anth) })_{2}\end{array}$ & C2 & 705.54 & 270 & Brown & 57.88 & 3.71 & 11.91 & 18.14 & $8.35(7.32)$ \\
\hline $\begin{array}{l}\mathrm{C}_{34} \mathrm{H}_{26} \mathrm{NiN}_{6} \mathrm{O}_{8} \\
\mathrm{Cu}(\mathrm{L})(\text { Anth })_{2}\end{array}$ & C3 & 705.30 & $250 \mathrm{~F}$ & Pail-brown & 57.90 & 3.72 & 11.92 & 18.15 & $8.32(7.03)$ \\
\hline $\begin{array}{l}\mathrm{C}_{34} \mathrm{H}_{26} \mathrm{CuN}_{6} \mathrm{O}_{8} \\
\mathrm{Cd}(\mathrm{L})(\text { Anth })_{2}\end{array}$ & $\mathrm{C} 4$ & 710.15 & 230 & Orange & 57.50 & 3.69 & 11.83 & 18.12 & $8.95(7.96)$ \\
\hline $\begin{array}{l}\mathrm{C}_{34} \mathrm{H}_{26} \mathrm{CdN}_{6} \mathrm{O}_{8} \\
\mathrm{Hg}(\mathrm{L})(\text { Anth) })_{2}\end{array}$ & C5 & 759.02 & 250 & Pail-brown & 53.80 & 3.45 & 11.07 & 16.861 & 14.81(13.57) \\
\hline $\mathrm{C}_{34} \mathrm{H}_{26} \mathrm{HgN}_{6} \mathrm{O}_{8}$ & $\mathrm{C} 6$ & 847.20 & $170-172$ & 2Dark browr & vn48.20 & 3.09 & 9.92 & 15.112 & 23.68(22.23) \\
\hline
\end{tabular}

\section{Mass Spectrum}

Mass Spectrum of Schiff base ligand is carried out to determine its molecular weight and fragmentation pattern as explained in Fig. 2 and Table 2. ${ }^{11,12}$

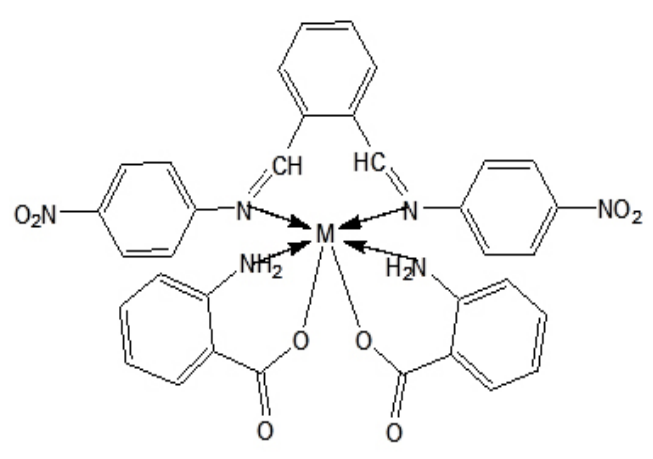

$\mathrm{M}(\mathrm{II})=\mathrm{Mn}, \mathrm{Co}, \mathrm{Ni}, \mathrm{Cu}, \mathrm{Hg}$ and $\mathrm{Cd}$

Fig.1. The synthesis route of $\left[\mathrm{L1}(\mathrm{M})(\text { Anth })_{2}\right]$ complexes
Table 2: The fragmentation data for the (L)

\begin{tabular}{ccc}
\hline Ligand & Assignments & Peak m/z \\
\hline & $M=\left(\mathrm{C}_{20} \mathrm{H}_{14} \mathrm{~N}_{4} \mathrm{O}_{2}\right)$ & 373 \\
$\mathrm{M}-\mathrm{N}_{2} \mathrm{O}_{4}=\mathrm{M}_{1}$ & 281 \\
$\mathrm{~L}$ & $\mathrm{M}_{1}-\mathrm{C}_{6} \mathrm{H}_{4}=\mathrm{M}_{2}$ & 206 \\
$\mathrm{M}_{2}-\mathrm{N}=\mathrm{CH}=\mathrm{M}_{3}$ & 179 \\
$\mathrm{M}_{3}-\mathrm{C}_{7} \mathrm{H}_{5} \mathrm{~N}=\mathrm{M}_{4}$ & 76 \\
\hline
\end{tabular}

\section{${ }^{1} \mathrm{H}-\mathrm{NMR}$ Spectral Data of Ligand}

The ${ }^{1} \mathrm{H}-\mathrm{NMR}$ spectrums of the synthesized Schiff base ligand (L) in DMSO-d6 are shown in Fig. 3 and Table 3 . The singlet signal appeared at $(\delta=2.45 \mathrm{ppm})$ can be assigned to the solvent DMSO. The multiple signals, ranged between ( $\delta=6.55-8.36$ ), are assigned to the aromatic protons of the phenyl, and the doublet signal at $(\delta=8.44)$ is attributed to the azomethine proton $(\mathrm{HC}=\mathrm{N})^{13,14}$. 


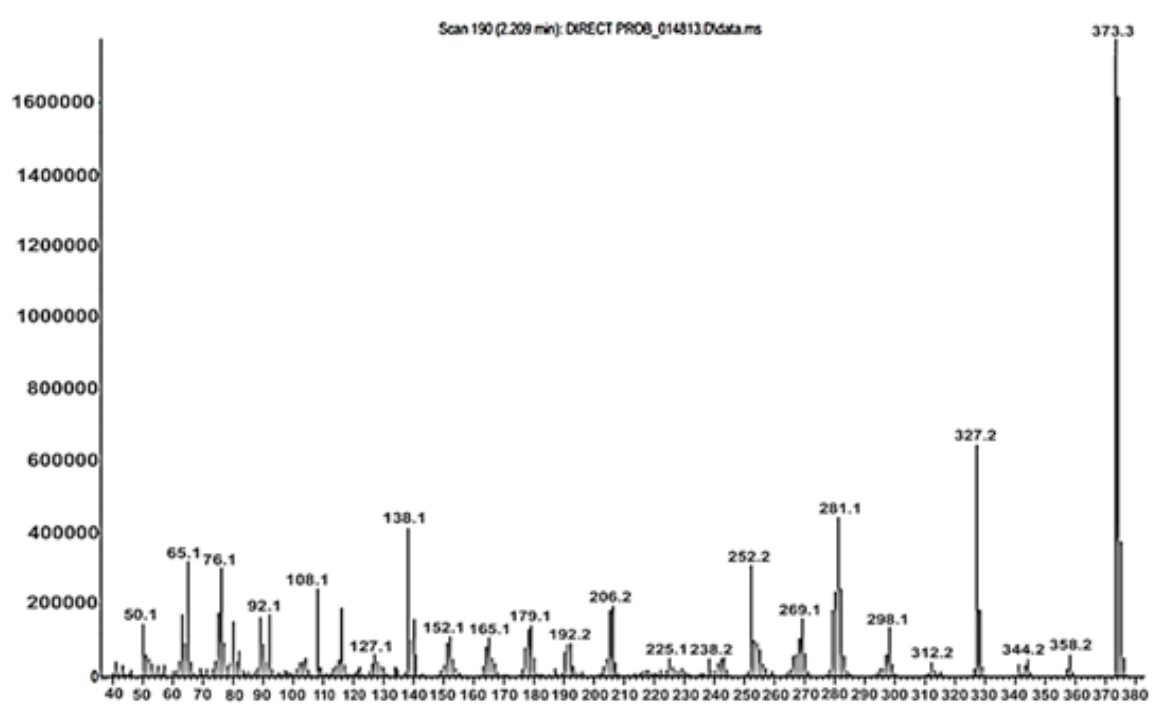

Fig. 2. Mass spectrum of ligand

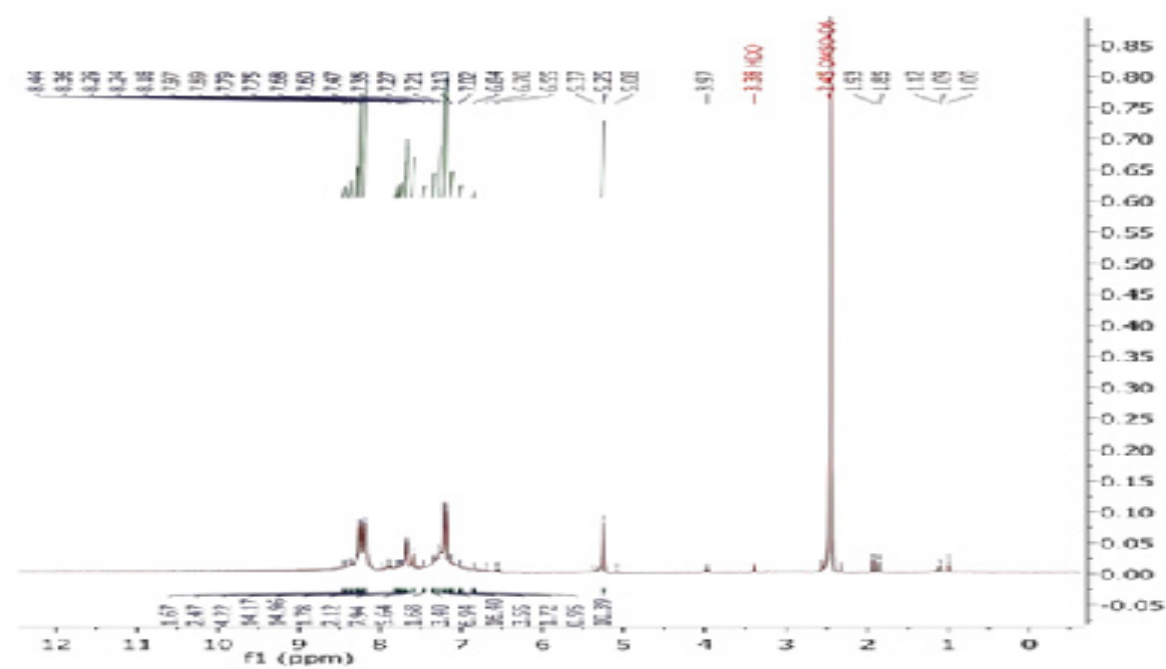

Fig. 3. ${ }^{1} \mathrm{H}-\mathrm{NMR}$ spctrum of ligand (L)

Table 3: 1H-NMR Spectral data for measured L and chemical shift in ppm

\begin{tabular}{ccc}
\hline Ligand & Functional group & $\delta(\mathrm{ppm})$ \\
\hline & DMSO-d6 & 2.45 \\
$\mathrm{~L}$ & $\mathrm{Ar}-\mathrm{H}$ & $6.55-8.36(12 \mathrm{H}, \mathrm{m})$ \\
& $\mathrm{N}=\mathrm{C}-\mathrm{H}$ & $8.44(2 \mathrm{H}, \mathrm{s})$ \\
\hline
\end{tabular}

\section{FTIR Spectra}

The FTIR spectrum of $(\mathrm{L})$ is in $\mathrm{KBr}$ disc in range of $(4000-400) \mathrm{cm}^{-1}$. Fig. 4 shows the weak absorption band at $3111 \mathrm{~cm}^{-1}$ which has been consigned for the $(\mathrm{C}-\mathrm{H})$ aromatic stretching vibration. The medium band at $1622 \mathrm{~cm}^{-1}$ is assigned to the $(\mathrm{HC}=\mathrm{N})$ stretching vibration, and the band at $1577 \mathrm{~cm}^{-1}$ is allocated for the $(C=C)$ stretching vibration ${ }^{15}$. The FTIR spectrum of Anthranilic acid shows bands of $\mathrm{v}(\mathrm{O}-\mathrm{H}), \mathrm{v}\left(\mathrm{NH}_{2}\right)$, vas $(\mathrm{COO})$, and us (COO) at (3390) and (3324, 3240), 1679, and $1486 \mathrm{~cm}^{-1}$ respectively ${ }^{16}$. In complexes, $\mathrm{v}(\mathrm{O}-\mathrm{H})$ is disappeared, and $v\left(\mathrm{NH}_{2}\right)$ is shifted to higher frequencies for all complexes without $\mathrm{C} 1$ and $\mathrm{C} 2$, making $\mathrm{NH}_{2}$ in an active location of coordinate. The bands of vas and us(COO) in all these complexes shifted to higher frequencies for vasy $(\mathrm{COO})$, and 
lower frequencies for usym(COO). Therefore, the difference between $\Delta$ as-s is equal to $(235-247) \mathrm{cm}^{-1}$ that indicates the carboxlate ion coordination with the metal ions, and it is considered as mono dentate donor ${ }^{17,18}$. New spectra have been appeared in the bands of all compounds in the regions (559-570) $\mathrm{cm}^{-1}$ which refer to $v(\mathrm{M}-\mathrm{O})$ mode $^{19}$. The bands at $(486-489) \mathrm{cm}^{-1}$ refer to $v(\mathrm{M}-\mathrm{N})$ mode 20,21 .

Table 4: FTIR details of $\mathrm{cm}-1$ free ligands and its compounds

\begin{tabular}{|c|c|c|c|c|c|c|c|c|}
\hline Comp. & $v(\mathrm{O}-\mathrm{H})$ & $\mathrm{v}(\mathrm{N}-\mathrm{H})$ & $\begin{array}{l}v(\mathrm{C}-\mathrm{H}) \\
\text { arom. }\end{array}$ & $\begin{array}{c}\mathrm{u}(\mathrm{COO}) \\
\text { as \& s }\end{array}$ & $\Delta$ as-s & $v(C=N)$ & $v(\mathrm{M}-\mathrm{N})$ & $v(M-O)$ \\
\hline L1 & ---- & ---- & 3111 & ---- & ---- & 1622 & ---- & ---- \\
\hline \multirow[t]{2}{*}{ Anth } & 3390 & 3321 & 2586 & 1679 & ----- & ------ & ---- & --- \\
\hline & & 3210 & & 1486 & & & & \\
\hline \multirow[t]{2}{*}{ C1 } & --- & 3305 & 3143 & 1693 & 239 & 1654 & 559 & 489 \\
\hline & & 3232 & 3082 & 1454 & & & 536 & \\
\hline \multirow[t]{2}{*}{$\mathrm{C} 2$} & ---- & 3303 & 3136 & 1693 & 235 & 1654 & 563 & 489 \\
\hline & & 3224 & 3086 & 1458 & & & & \\
\hline \multirow[t]{2}{*}{ C3 } & ---- & 3363 & 3120 & 1693 & 239 & 1654 & 567 & 489 \\
\hline & & 3302 & 3082 & 1454 & & & & \\
\hline \multirow[t]{2}{*}{$\mathrm{C} 4$} & ---- & 3402 & 3120 & 1693 & 235 & 1600 & 574 & 489 \\
\hline & & 3275 & 2924 & 1458 & & & & \\
\hline \multirow[t]{2}{*}{ C5 } & ---- & 3360 & 3136 & 1693 & 243 & 1654 & 574 & 489 \\
\hline & & 3290 & 3086 & 1450 & & & & \\
\hline \multirow[t]{2}{*}{ C6 } & ---- & 3329 & 3113 & 1693 & 247 & 1654 & 563 & 489 \\
\hline & & 3263 & 3078 & 1446 & & & & \\
\hline
\end{tabular}

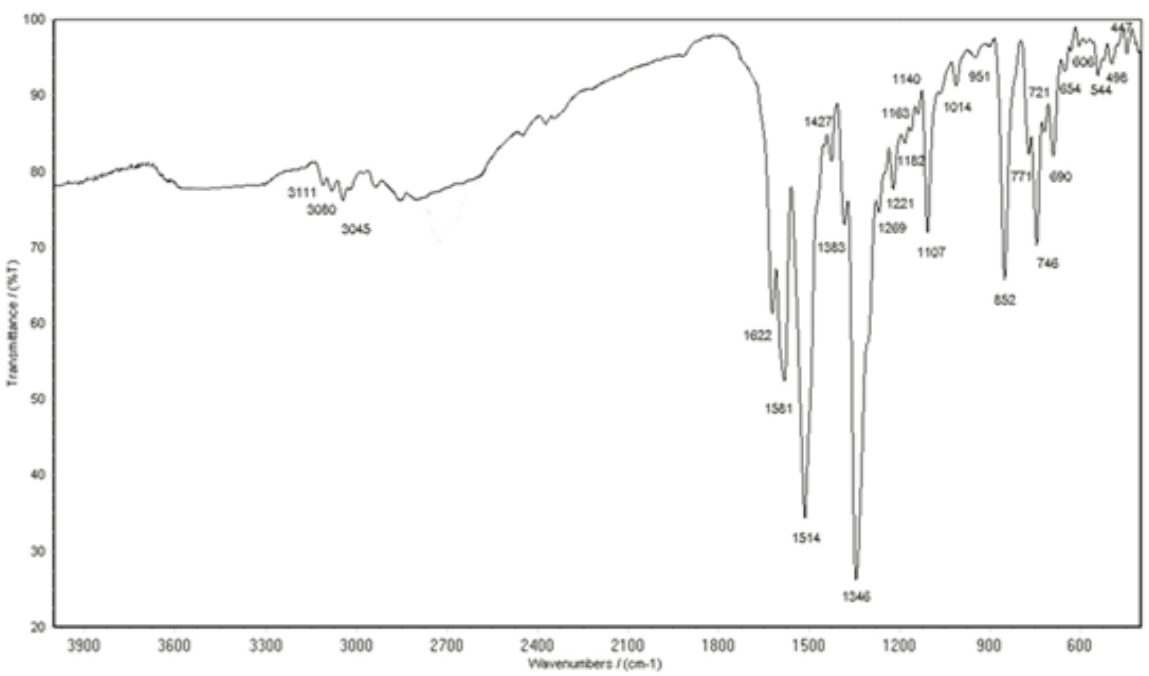

Fig. 4. FTIR spectrum of ligand $L$

Electrnic Spectra, Molar Conductivity, and Magnetic Moments

The UV-Vis. band of ligand $(L)$ is shown in Fig. 5. The spectrum exhibits three peaks; one of them is in $(286 \mathrm{~nm})$ due to $\left(\pi \rightarrow \pi^{*}\right)$ electronic shift while the others are in $(345$, and $358 \mathrm{~nm})$ due to $\left(n \rightarrow \pi^{*}\right)$ electronic shift ${ }^{22,23}$. The UV-Vis. spectrum of $\mathrm{C} 1$ complex shows five absorption peaks. The 
three absorption peaks at (264, 329 and 345$)$ $\mathrm{nm}$ are due to intra ligand comparably with the spectrum of (L1). The fourth absorption peak is at $(380 \mathrm{~nm})$ assigned for charge transfer (C. T), and the last one has a weak intense peak at $(448 \mathrm{~nm})$, which indicates that there is a $(d-d)$ electronic transition type ${ }^{6} \mathrm{~A} 1 \mathrm{~g} \rightarrow{ }^{4} \mathrm{~T}_{2} \mathrm{~g}(\mathrm{G})$, and this proves an octahedral structure around $\mathrm{Mn}$ (II) complex ${ }^{24}$. The UV-Vis band of C2 compound has five absorption peaks; three absorption peaks are at (279, 327 and 347$) \mathrm{nm}$ assigned for intra ligand, and two new absorption peaks, with weak intensity, are at $(739$ and $790 \mathrm{~nm})$ due to $(\mathrm{d}-\mathrm{d})$ type ${ }^{4} \mathrm{~T}_{1} \mathrm{~g}(\mathrm{~F})$ $\rightarrow{ }^{4} \mathrm{~A}_{2} \mathrm{~g}(\mathrm{~F})$ transition; this indicates that there is an octahedral structure around $\mathrm{Co}$ (II) complex ${ }^{25,26}$. The UV-Vis. band of $\mathrm{C} 3$ compound shows five absorption peaks, the low absorption peaks are at (267 and 345) $\mathrm{nm}$ assigned for intra ligand. The absorption peak at $(357 \mathrm{~nm})$ is attributed to charge transfer (C.T). C3 has weak intensity (777 and 826) $\mathrm{nm}$ due to types ${ }^{3} \mathrm{~A}_{2} \mathrm{~g}(\mathrm{~F}) \rightarrow{ }^{3} \mathrm{~T}_{1} \mathrm{~g}(\mathrm{~F})$ and ${ }^{3} \mathrm{~A}_{2} \mathrm{~g}(\mathrm{~F}) \rightarrow{ }^{3} \mathrm{~T}_{2} \mathrm{~g}(\mathrm{~F})$ transitions, which support the existence of an octahedral structure around $\mathrm{Ni}(\mathrm{II})$ complex $^{27}$. The UV-Vis. spectrum of $\mathrm{C} 4$ complex displays three absorption peaks; the highest absorption peaks at $(345 \mathrm{~nm})$ is assigned to charge transfer (C.T), and the peak at
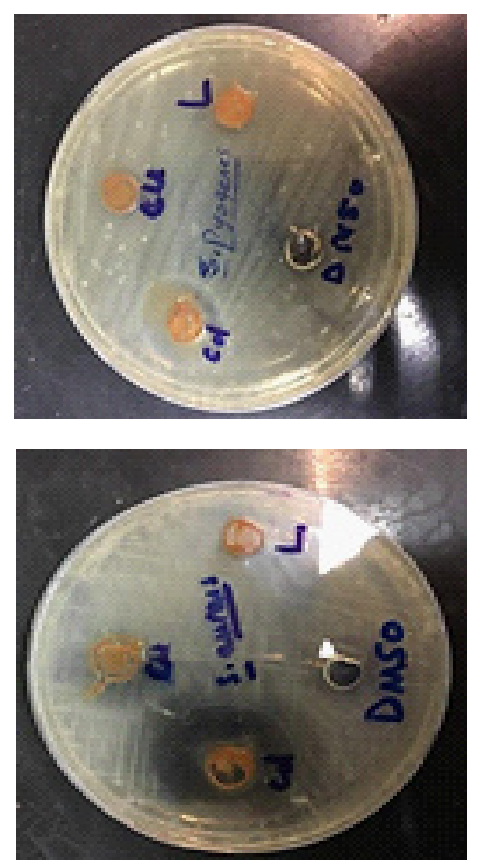

Fig. 5. The zone of inhibition for all compounds

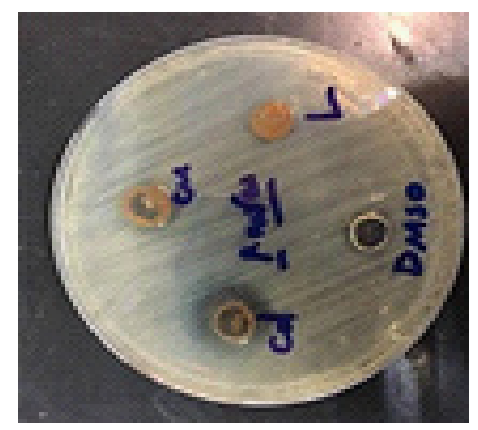

$(270 \mathrm{~nm})$ is due to intra ligand. The third absorption peak with weak intensity at $(800 \mathrm{~nm})$ is attributed to ${ }^{2} \mathrm{Eg} \rightarrow{ }^{2} \mathrm{~T}_{2} \mathrm{~g}$. These peaks are congruence in location with the researches of octahedral $\mathrm{Cu}(\mathrm{II})^{28}$. The UV-Vis. spectra of $\mathrm{C} 5$ and $\mathrm{C} 6$ complexes, show absorption peaks at (264 and 266) nm, respectively, and are assigned to intra ligand. The peaks at (342 and 345) $\mathrm{nm}$ are due to charge transfer (C.T) that shows diamagnetic as perspective from their electronic arranging. They support that there is an octahedral structure around $\mathrm{Cd}(\mathrm{II})$ and $\mathrm{Hg}(\mathrm{II})$ complexes $^{29}$. The molar conductivities indicate that all complexes are non-electrolytes. Magnetic moment values show that there is an octahedral arrangement around the metal (II) ions ${ }^{18}$ as revealed in Table 5.

\section{Boiological Activity}

The Schiff base ligand [L] and the corresponding metal compounds under study are tested against four antimicrobial activities; psuedomonas aruginosa and Escharia coli (gram-), Staphylococcus aureus and Streptococcus pyogenes $(g r a m+)$ by plate well into agar nutrient method. Antimicrobial activity is expressed in millimeters by measuring the diameters of the inhibitory region and contrasting with the DMSO control; the values are explained in Table 6, Fig. 5 and chart- 30,31 .

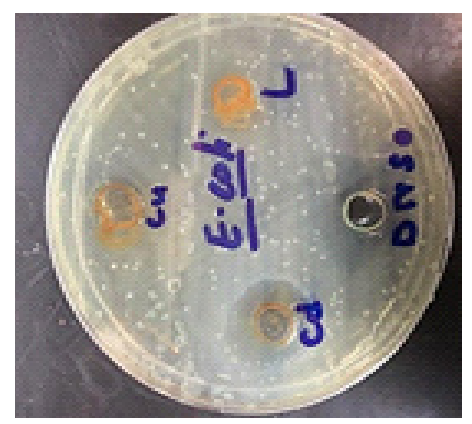


Table 5: Spectral and magnetic moments $(\mathrm{nm})$ of the complexes

\begin{tabular}{|c|c|c|c|c|c|c|}
\hline Compounds & $\lambda \max$. & $v \mathrm{~cm}^{-1}$ & $\begin{array}{c}\lambda \max . \\
\mathrm{mol}^{-1} . \text { L.cm }\end{array}$ & Assignments & $\begin{array}{c}\text { Molar } \\
\text { Conductivity }\end{array}$ & $\mu$ eff (BM) \\
\hline \multirow[t]{3}{*}{$L$} & 286 & 34965 & 893 & $\pi \rightarrow \pi^{*}$ & --- & --- \\
\hline & 345 & 28986 & 2019 & $\mathrm{n} \rightarrow \pi^{*}$ & & \\
\hline & 358 & 27933 & 1134 & $\mathrm{n} \rightarrow \pi^{\star}$ & & \\
\hline \multirow[t]{5}{*}{$\mathrm{C} 1$} & 264 & 37879 & 1006 & Intra-ligand & & 5.72 \\
\hline & 329 & 30395 & 1783 & Intra-ligand & & \\
\hline & 345 & 28986 & 1973 & Intra-ligand & 0.95 & \\
\hline & 380 & 26316 & 75 & C.T & & \\
\hline & 448 & 22321 & 22 & ${ }^{6} \mathrm{~A}_{1} \mathrm{~g} \rightarrow{ }^{4} \mathrm{~T}_{2} \mathrm{~g}(\mathrm{G})$ & & \\
\hline \multirow[t]{5}{*}{$\mathrm{C} 2$} & 279 & 35842 & 1051 & Intra-ligand & 1.09 & 4.72 \\
\hline & 327 & 30581 & 1228 & Intra-ligand & & \\
\hline & 347 & 28818 & 1454 & C.T. & & \\
\hline & 739 & 13532 & 38 & ${ }^{4} T_{1} g(F) \rightarrow{ }^{4} A_{2} g(f)$ & & \\
\hline & 790 & 12658 & 35 & ${ }^{4} \mathrm{~T}_{1} \mathrm{~g}(\mathrm{~F}) \rightarrow{ }^{4} \mathrm{~T}_{2} \mathrm{~g}(\mathrm{f})$ & & \\
\hline \multirow[t]{5}{*}{ C3 } & 267 & 37435 & 1000 & Intra-ligand & 1.83 & 4.61 \\
\hline & 345 & 28986 & 1635 & Intra-ligand & & \\
\hline & 357 & 28011 & 1011 & C.T. & & \\
\hline & 777 & 12870 & 15 & ${ }^{3} \mathrm{~A}_{2} \mathrm{~g}(\mathrm{~F}) \rightarrow{ }^{3} \mathrm{~T}_{1} \mathrm{~g}(\mathrm{~F})$ & & \\
\hline & 826 & 12107 & 13 & ${ }^{3} \mathrm{~A}_{2} \mathrm{~g}(\mathrm{~F}) \rightarrow{ }^{3} \mathrm{~T}_{2} \mathrm{~g}(\mathrm{~F})$ & & \\
\hline \multirow[t]{3}{*}{$\mathrm{C} 4$} & 270 & 37037 & 1182 & Intra-ligand & 0.89 & 1.83 \\
\hline & 345 & 28986 & 2023 & C.T. & & \\
\hline & 800 & 12500 & 49 & ${ }^{2} \mathrm{Eg} \rightarrow{ }^{2} \mathrm{~T}_{2} \mathrm{~g}$ & & \\
\hline \multirow[t]{2}{*}{ C5 } & 264 & 37879 & 1010 & Intra ligand & 0.87 & Dia. \\
\hline & 342 & 29239 & 2312 & C.T. & & \\
\hline \multirow[t]{2}{*}{ C6 } & 266 & 37594 & 1143 & Intra ligand & 1.57 & Dia \\
\hline & 345 & 28986 & 2063 & C.T. & & \\
\hline
\end{tabular}

Table 6: Antibacterial performance of the ligand and their metal compounds

\begin{tabular}{ccccc}
\hline Comp. & Staphylococcus aureus & Streptococcus pyogenes & Psuedomonas aruginosa & Escharia coli \\
\hline DMSO & zero & zero & zero & Zero \\
L & zero & zero & zero & Zero \\
C1 & zero & zero & zero & Zero \\
C2 & 16 & 14 & 20 & 17 \\
C3 & zero & zero & zero & Zero \\
C4 & 25 & zero & zero & Zero \\
C5 & 30 & 21 & 17 & 20 \\
C6 & 30 & 25 & 18 & 17 \\
\hline
\end{tabular}

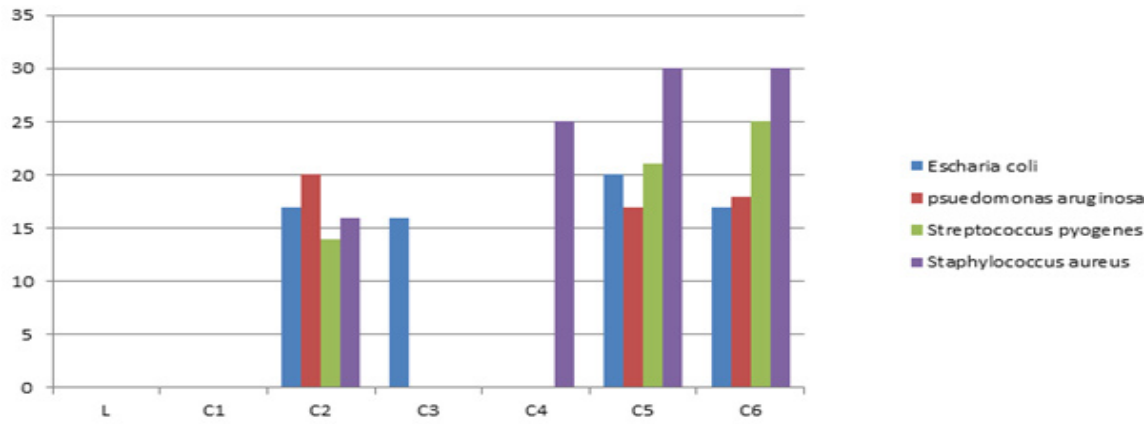

Chart 1 : The inhibition zones of the compounds 


\section{CONCLUSION}

The new Schiff base derived from o-phathalaldehyde with $p$-nitroaniline is synthesized and characterized. The results show the coordination of $\mathrm{L}$ format with metal ions through the $\mathrm{N}$ as a donor atom. The results of the electron spectra and the magnetic susceptibility of all complexes show that these complexes are of octagonal geometry. The composite compounds are studied as antimicrobial, and the results reveal that $\mathrm{C} 2, \mathrm{C} 5$ and $\mathrm{C} 6$ complexes have various activities against bacteria, while L, C1 and $\mathrm{C} 2$ are inactive against two types of bactria.

\section{ACKNOWLEDGEMENT}

The authors express their sincere appreciation to Chemistry Department, College of Education for Pure Sciences in Ibn -Al Haitham, University in Baghdad, Iraq for the financial support of this study.

\section{REFERENCES}

1. Anand, P.; Patil V.M.; Sharma, V.K.; Khosa, R.L.; Masand, V. N. International Journal of Drug Design and Discovery., 2012, 3, 851.

2. Krishna, E.R.; Reddy, P.M.; Sarangapani, M.. Spectrochim. Acta Part A-Molecular and Biomolecular Spectroscopy., 2012, 97, 189-196.

3. Vaidehi, B.N.B.; Surya, T.K.; Prabhakar, N.V. Int J Pharm Bio Sci., 2013, 4(4), 829 - 837.

4. Sreenivas, V.; Aruna, M.; Prasanna, B.; Ravinder, V. JCHPS., 2014, 37-38.

5. Shakir, M.; Khanam, S.; Azam, M.; Aatif, M.; Firdaus, F. J. Coord. Chem., 2011, 64(18), 3158-3168.

6. Sandhanamalar, D.; Vedanayaki, S.; Rajavel, R. Journal of Pharmacy and technology 2012, 4(1), 4018-4031.

7. Chan, K.E.; Edelman, E.R.; Wenger, J.B.; Thadhani, R.I.; Maddux, F.W. Dabigatran and Rivaroxaban Use in Atrial Fibrillation Patients on Hemodialysis, Circulation., 2015.

8. Voguri, H. B.; Venkateswara, K.R.; Podisetty, H.; Badde, S.; More, A. Int. J.ChemTech Research., 2017, 10 (5), 136-143.

9. Venugopal, P.; Bhaskar, S.; Muralidhar, P.R. Int.J. ChemTech Research., 2018, 11(01), 167-176.

10. Sandhanamalar, D., Vedanayaki, S.; Rajave, R. IJPT., 2012, 4(1), 4018-4031.

11. Patel, K.S.; Rinehart, K.L.; Bailar, J. C. Organic Mass Spectrometry., 1970, 4, 441.

12. Mohamed, G.G.; Omar, M.M.; Hindy, A. M. Turk. J. Chem., 2006, 30, 361.

13. Simons, W. W. The Sadtler Handbook of Proton NMR Spectra, Sadtler Re-search Laboratories, Philadelphia, Sadtlerk., 1978,

14. Ahlam, J.A.; Asmaa, M. N. K. J Inorg Biochem., 2013, 1-14.

15. Socrates, G. Infrared Characteristic Group Frequencies. 2nd. ED. John Willey Sons, 1994, 98.

16. Lekaa, K.A.K. Synthesis, Characterization And Biological Evaluation of New Schiff
Bases Mixed Ligand Metal Complexes of Some Drugs, Submitted to Collage of education for pure sciences Ibn Al Haitham of Baghdad University in partial fulfillment of the requirements for the degree of doctorate of science in chemistry., 2016.

17. Pisarewicz, K.; Mora, D.; Flueger, P.F.; Fields, G.; Marí, F. J. Am. Chem. Soc., 2005, 127, 6207.

18. Vogel, A.I.A. Text Book of Quantitative Inorganic Analysis. 2nd Ed. (Longman, London)., 1978, 694.

19. Raju, A.; Saravanan, S.; Ekamparam, A.; Rangappan, R. Chem Sci Trans., 2017, 6(2), 277-287.

20. Rawate, G.D. Chemical Science Transaction., 2014, 3(4), 1396-1399.

21. Taghreed, H.A.N.; Lekaa, K.A.K. Chemistry and Materials Research., 2015, 7(3), 32-39.

22. Sangamesh, A.; Patil, M.; Ajaykumar, M.; Kulkarni, D.; Badami, P. S. Complex Metals., 2017, 03, 128.

23. Lever, A.B.P. Inorganic Electronic Spectroscopy. 2nd Ed. Elsevier. in Amsterdam, New York., 1984.

24. Rehab, K.A.S.; Lekaa, K.A.K.; Wurood, A. J. Baghdad Science Journal., 2017, 14(2), 390-402.

25. Lateef, S.M.; Sarhan, B. M.; AISaedi, W. A. J. Inter. J. of Eng. Sci. and Research Techn., 2015, 4(2), 606-620.

26. Fernandez, T. M. J. Inter. J. of Chem., 2013, 9(2), 33-40.

27. Meixian, H.u.; Ning, L.i.; Kemin, Yao. Front. Chem.China., 2006, 4, 369-373.

28. Sharma, R.; Samadhiya, P.; Srivastava, S.D.; Srivastava, S. K. Org. Commun., 2011, 4(2), 42-51.

29. Dudley, H.W.; Fleming, I. Part A: Spectroscopic methods in organic chemistry. 3nd Ed., England.,1980.

30. Reham, H.; Hassan, A.; Manal, M.; Nehad, A. L. J. of Chem., 2013, 20(13), 10.

31. Taghreed, H.A.N.; Lekaa, K. A. K. J. of Med. Sci., 2016, 3(2), 64-75.21. 